Revista de Indias, 1999, vol. LIX, núm. 217

\title{
¿SEGREGACIÓN O ASIMILACIÓN? LA POLÍTICA INDIANA EN AMÉRICA MERIDIONAL A FINES DEL PERÍODO COLONIAL
}

POR

\author{
GUILLERMO WILDE \\ Instituto de Ciencias Antropológicas \\ Universidad de Buenos Aires
}

En este trabajo analizamos el trasfondo cultural de algunas medidas legales tomadas por la Corona, focalizando su carácter de constructoras de imágenes hegemónicas del Estado articuladas con las de las poblacionales nativas.

En 1768 fueron expulsados los jesuitas de los pueblos guaraníes de la «Provincia Jesuítica del Paraguay». Por más de 150 años estas reducciones habían respondido a una política indigenista de segregación, coherente con las directivas de la legislación indiana. El nuevo gobierno implementó una serie de medidas tendientes a reforzar la imagen del Estado, rompiendo con el paradigma segregacionista anterior y definiendo una tendencia a la asimilación de las poblaciones nativas en la sociedad colonial.

\section{LEGISLACIÓN Y CATEGORÍAS SOCIOCULTURALES}

Quienes trabajamos sobre el período colonial en América, pocas veces nos cuestionamos sobre los mecanismos por los cuales la legislación indiana construyó categorías y realidades socioculturales. No parecemos haber ido mucho más lejos de afirmar que el término «Indio» fue en realidad una categoría colonial, construida con el propósito de homogeneizar una inmensa diversidad cultural, y que sólo podía encontrar sentido en el binomio, un tanto simplista y algo anticuado «dominantes-dominados».

Desde la conquista española en América, el status de las poblaciones nativas americanas en la legislación viene siendo, sin solución de continuidad, motivo de

R. I., $1999, \mathrm{n}^{\circ} 217$ 
constantes definiciones y redefiniciones ${ }^{1}$. Las políticas indigenistas de la Corona a todo lo largo del período colonial, estuvieron condicionadas por determinadas concepciones acerca de estas poblaciones, que por supuesto variaron con el discurrir de los años y en general no dejaron de estar supeditadas a una concepción de la conquista como empresa «civilizadora y evangelizadora» ${ }^{2}$. Simultáneamente, esta doble identificación del «nosotros conquistador» conllevaba concepciones referidas al «otro». El discurso oficial debió codificar imágenes que le permitieran interpelar a sus «súbditos» a pesar de la diversidad y las contingencias históricas. Y a estas realidades «otras», precisamente, se orientaba la legislación.

Bajo esta perspectiva, la diversidad sociocultural era concebida en definitiva como manifestaciones de «infidelidad y salvajismo» epitomizadas en la frase «Sin Rey sin fe». Pese a la apariencia unívoca de estas consignas, lejos estaba el incipiente Estado español de fines de siglo XVII de lograr una homogeneidad cultural perdurable en sus dominios.

La legislación era uno de los recursos más definidos con que contaba este Estado incipiente para erigirse como referente legal supremo. Pero ¿cuán eficaz resultaba este método de legitimación?. Aún cuando en buena parte de los casos los resultados eran poco felices, no cabe dudas de que la documentación administrativa constituía comúnmente, como monopolio de la ley, uno de los principales mecanismos de control y referente clave a la hora de dirimir conflictos. $\mathrm{La}$ legislación ocupaba un lugar central en el discurso oficial.

Hasta el siglo XVII, la legislación indiana en general había sido una seguidilla de intentos del Estado Colonial español por establecer un control directo sobre sus dominios, proscribiendo prerrogativas del sector conquistador y de esa forma evitando también la formación de un «feudalismo americano». Pietschmann ha analizado brillantemente el papel de la alianza Corona-iglesia en este proceso, resaltando el carácter político de la empresa de conquista. En este sentido podemos pensar a la legislación indiana, por lo menos durante la conquista temprana, como expresión de la imbricación entre Corona e Iglesia y como corpus instituyente del «monopolio moral» de la conquista.

«No hay Indias sin Indios», y los intentos del Estado se orientaban principalmente al control directo de las poblaciones nativas, limitando al sector conquistador. ${ }^{3}$ En este sentido, la legislación fundaba y actualizaba constantemente

1 Aún en la actualidad la definición de «lo indígena» es tema de debate en foros internacionales. De gran relevancia es el Proyecto de declaración de Naciones Unidas de 1994 sobre los derechos de los Pueblos Indígenas, el cual se pliega a la legislación Internacional en materia de Derechos Humanos. Cfr. El mundo Indigena. Copenhague, IWGIA, 1993-1994, p. 175-187.

2 PIETSCHMANn, Horst: El Estado y su evolución al principio de la colonización española de América. México, Fondo de Cultura Económica, 1989.

3 Las leyes de Burgos (1512) y Nuevas (1542) son dos claros ejemplos de aplicación parcial y poco feliz de mecanismos de control. Una buena síntesis del proceso de conquista y sus avatares

R. I., $1999, \mathrm{n}^{\circ} 217$ 
el «problema del Otro» a través de sucesivas inscripciones y reinscripciones. La nociones acerca del «nosotros sociocultural», conllevaban percepciones de la «alteridad» a la cual la legislación iba dirigida. Este espacio legal, debía interpelar a los actores para lograr una adhesión que no fuera pura y exclusivamente coercitiva ${ }^{4}$.

Si bien estas leyes en apariencia tenían carácter puramente administrativo, las coordenadas culturales en las que se inscribían no eran nada despreciables. Por el contrario, eran portadoras de valores y conceptos culturales naturalizados sobre la imagen que España buscaba construir de sí misma y de sus pueblos conquistados. Por otra parte, no se trataba de imágenes coherentes pues arrastraban las contradicciones propias de un estado en proceso de formación.

En un trabajo dedicado al análisis de la «visita» como institución indiana, Guevara Gil y Salomon analizan el modo como este mecanismo de control no sólo representaba las realidades culturales nativas, sino que también las construía a través de una serie de escenificaciones rituales ${ }^{5}$. Estas construcciones resultaban útiles a los actores para maniobrar pues la condición étnica inscripta en las «visitas» era también una condición legal que permitía y limitaba a los actores en su desenvolvimiento social. De modo similar, sostenemos, operaban las fuentes legislativas: definiendo los límites del orden sociocultural. Específicamente la legislación indigenista y las crónicas europeas gestaban categorías sociales y étnicas, instituían diferencias socioculturales; contribuían, en fin, a modelar la tradición de las relaciones hispano-indígenas.

La complejidad de un mundo americano heterogéneo fue motivo de sucesivos ensayos homogeneizadores que no tardaban en erosionarse por el peso mismo de su incongruencia con los movimientos poblacionales concretos. Hacia el siglo XVII los «otros» no eran únicamente las poblaciones nativas, sino también los

\footnotetext{
legislativos se puede encontrar en ElLIOT, John: «La conquista española y las colonias de América», en Bethell, Leslie (ed.): Historia de América Latina. Barcelona, Cambridge Univ. Press/Ed. Crítica, vol 1, 1990. Y también de Elliot en el segundo volumen de la misma colección: «España y América en los siglos XVI y XVII».

4 Esta quiza sea una de las claves para comprender la introducción y aceptación de símbolos de prestigio peninsulares en las sociedades nativas. El Estado como referente legal buscaba legitimidad y consenso mediante interpelaciones de fuerte carácter simbólico, como la ritualización de los espacios. Los abundantes trabajos de investigación locales nos han enseñado que las relaciones hispano-indígenas constituían procesos de intercambio complejos e irreductibles al dualismo de los análisis tradicionales del tipo dominadores-dominados o vencedores-vencidos. Estas relaciones se encontraban atravesadas por múltiples mediaciones y contradicciones, difíciles de aprehender desde perspectivas tan globales.

5 Guevara Gil, Jorge Armando y SAlOMON, Frank: «La visita personal de indios: ritual político y creación del «indio» en los Andes Coloniales», en Cuadernos De Investigación. PUCP/Instituto Riva-Agüero. 1/1996, pp. 15-48.
} 
propios españoles instalados en América, que habían llegado tarde al reparto, quedando relegados como marginales o como clases sin privilegios ${ }^{6}$.

El siglo XVIII asiste en general a un fuerte movimiento reformista y en particular a un rediseño de la política indiana. Estos cambios evidenciaban la imagen que el estado intentaba construir de sí mismo, pero también un cambio de imágenes referidas a los «otros» que trataba de interpelar. En este proceso de cambio el Estado no se presenta como un bloque homogéneo, sino más bien como una tensión de fuerzas internas en pugna y al borde del estallido.

Durante los siglos XVI y XVII la política indigenista había tenido fuerte carácter segregacionista. La «República de Indios» había sido un gran intento homogeneizador, en el marco del cual se formaron las primeras reducciones indígenas. Pero hacia mediados del siglo XVIII esta política comienza a sufrir fuertes cambios como efecto de la inercia de una realidad americana cada vez más heterogénea étnicamente. En forma paralela, se difundían en Europa las ideas ilustradas que influenciaron la corriente reformista iniciada con los borbones. Una serie de ensayos terminarían por inclinar la balanza hacia un discurso que, no sin contradicciones, estaba fuertemente identificado con el asimilacionismo. Este viraje implicaba una resignificación de las imágenes referidas al «Indio».

Este es el clima general en el que se produce la expulsión de los jesuitas en el Río de la Plata. La política indigenista de la orden había estado alineada a un acendrado segregacionismo del cual los pueblos guaraníes constituían un paradigma. Después de la expulsión, una serie de disposiciones conocidas como «Ordenanzas de Bucareli» recayeron en los pueblos, reflejando un viraje sustantivo en la política indiana.

Nuestro propósito en este trabajo es analizar una manifestación particular de esta combinación de imágenes y políticas estatales, que por cierto mucho nos revela de la manera como España comenzaba a concebirse a sí misma. Aquí exploraremos el condicionamiento sociocultural de la política indigenista a fines del período colonial y la instrumentación de imágenes referidas a las poblaciones nativas en un corpus legal específico: las «Ordenanzas» para el gobierno de los pueblos guaraníes después de la expulsión de los jesuitas. A partir de la tesitura terminológica y el registro conceptual de estas «Ordenanzas» reconstruiremos la textura contextual que les daba sentido.

La lectura de fuentes legales a menudo resulta por demás tediosa para antropólogos e historiadores de la cultura. La opción siempre presente de analizar fuentes más seductoras desde el punto de vista de las prácticas socioculturales, ha llevado a estos investigadores a relegarlas del análisis. Por otra parte, una limitación común de los trabajos dedicados al abordaje de estas fuentes es que propen-

6 LOCKHART, James: «Organización y cambio social en la América española colonial», en Bethell, Leslie (ed.): Historia de América Latina. Barcelona, Cambridge Univ. Press/Ed. Crítica, vol. 4, 1990, pp. 63-108.

R. I., $1999, \mathrm{n}^{\circ} 217$ 
den al descriptivismo, transformándose, a veces, en inventarios ordenados de ideas o sistematizaciones acríticas de su contenido textual.

\section{EL ESTADO ESPAÑOL Y SUS COLONIAS AMERICANAS}

A principios del siglo XVIII, eran varios los síntomas de debilidad del poder estatal sobre sus dominios americanos. La Corona española paulatinamente perdía el control sobre sus colonias americanas, razón por la cual una reforma político-administrativa en gran escala resultaba inminente. Pero es cierto que gran parte de las reformas que la monarquía debía llevar a cabo contradecían muchos de los principios ideológicos en que se sustentaba la sociedad de Antiguo Régimen.

La transición a una sociedad plenamente moderna debía acarrear en el caso de España fuertes contradicciones ya que la monarquía no podía erradicar las instituciones de una sociedad estamental sin ocasionar una crisis. Por esto, la transición fue ante todo un lento proceso de resignificación conceptual en el que categorías tradicionales comenzaron a llenarse de nuevos contenidos.

El conjunto más fuerte de medidas se implementa hacia fines del siglo XVIII, y particularmente en el Río de la Plata esta reforma adquiere gran relevancia ${ }^{7}$. La Corona, ahora en manos de los Borbones, estaba preocupada ante todo por imponer su control directo allí donde existían sectores intermediarios que lo obturaban (gobiernos locales) y extenderlo allí donde no había llegado (territorios no colonizados). Con este doble propósito buscaba redefinir su relación con sus súbditos americanos, operación que necesariamente implicaba una redefinición de la imagen y status de estos sujetos frente al Estado.

Las principales medidas estaban orientadas a suprimir actores intermedios, tanto civiles como eclesiásticos, que obstaculizaban la acción de la Corona, definiendo jurisdicciones político-administrativas con sujeción directa a la misma y de control más efectivo a través de funcionarios especialmente designados. Otro imperativo era definir, por coerción o consentimiento, los límites territoriales tanto interiores como exteriores, de modo que no se viera perjudicada la «seguridad» de las ciudades y la actividad comercial. Asimismo debían fomentarse la apertura y legalización de nuevas rutas marítimas de comercio.

La gestión de los Austrias, lejos había estado de lograr estos objetivos. Su intervención se había retraído respecto de los agentes locales, en manos de quienes en definitiva se encontraba el control efectivo. Aún cuando el Estado español había realizado una serie de intentos por centralizar su dominio en las colonias, los gobiernos locales conseguían desbaratar sus planes apelando a diferentes

7 En el caso del Río de la Plata, las reformas político-administrativas de mayor relevancia fueron la creación del virreinato en 1776 y el Régimen de Intendencias en 1782. Aunque en verdad estos cambios estuvieran condicionados por el incremento de actividades económicas como el comercio, para el cual en 1778 se crea un Reglamento General. 
recursos. Un alto grado de corrupción se encontraba enquistado en los gobiernos locales, y tenía como soporte redes clientelares y parentales a veces centenarias, que impulsaban la autonomía respecto de la Corona. Generalmente, los cabildos se encontraban divididos en facciones locales más o menos coincidentes con intereses de familia ${ }^{8}$. La corrupción, como señala Lorandi, parecía una práctica cotidiana en todo el continente en el siglo XVII, que además contaba con la anuencia de la Iglesia.

Era justamente la Iglesia otro actor al cual la corona debía limitar en su proceso de reforma. Si bien esta institución había sido el aliado principal de la corona a lo largo del proceso de conquista, pronto comenzó a exhibir fisuras internas que básicamente enfrentaban al clero secular con el regular, pero también eran evidentes los roces entre las órdenes regulares por disidencias en materia de teoría moral. La pugna de fondo era en definitiva la que enfrentaba al papado con la Corona como cabezas máximas de la Iglesia.

La institución del Real Patronato había expresado hasta entonces un maridaje ejemplar entre la Santa Sede y la Corona española como «monopolio moral» de la conquista. Esta institución, legitimaba al Rey como máxima autoridad civil y eclesiástica en la empresa conquistadora y erigía soberana a la corona. Con el tiempo germinaría una Iglesia estatista que se afianzaría en el siglo XVIII. Es precisamente en la segunda mitad de ese siglo que la corona profundizó su influencia en asuntos religiosos impulsando sobre todo al clero secular, más directamente ligado al rey, y eliminando en la medida de sus posibilidades a intermediarios como las órdenes regulares que, aunque también sujetas al Real Patronato, eran fieles a la Santa Sede y se estructuraban de acuerdo a cierto «corporativismo jerarquizado» que impedía una injerencia directa sobre sus fueros. La corriente de pensamiento conocida como regalismo es la expresión más radical de la intervención del Estado en asuntos eclesiásticos 9.

8 Lorandi explora esta problemática en un trabajo dedicado al análisis de la ética pública y privada a fines del XVIII. LORANDI, Ana María: «Facciones, poder y ética en el siglo XVIII». Manuscrito presentado al V Congreso Internacional de Etnohistoria, 1998. De la misma autora puede consultarse también De quimeras, rebeliones y utopías. La gesta del inca Pedro Bohorques. Perú, Pontificia Universidad Católica del Perú, 1997. En la primera parte de este libro, Lorandi vincula el problema del mestizaje («las alianzas espúreas») y el criollaje a la gestación de círculos locales autonomistas. Sobre las redes parentales en el Tucumán Colonial pueden consultarse: BoIXAdos, Roxana: Tierra de hombre de cuatro abolengos. Parentesco y familia en La rioja Colonial. Tesis de Maestría, Museo Nacional, Programa de Posgraduación en Antropología Social, Universidad Federal de Río de Janeiro, 1996.

9 La pugna entre poder civil y eclesiástico, aunque parezca paradójico, se libró sobre todo al interior de la Iglesia entre las tendencias estatales, leales a la corona, y las afiliadas por voto de obediencia al papado. La polémica culminaría a fines del siglo XVIII con la expulsión de los jesuitas y la hegemonía de la vertiente estatista y las formulaciones del regalismo. HERA, Alberto: Iglesia y corona en la América española. Madrid, MAPFRE, 1992. En el Río de la Plata, las disidencias entre la Corona y el Papado comienzan también a manifestarse en la escisión entre Iglesia estatalista e Iglesia ultramontana. Antes de la expulsión, la Compañía de Jesús tenía enfrentamien- 
La disputa entre la Iglesia y el sector de los encomenderos tenía una larga duración en los dominios americanos y no era nada ajena por cierto a la construcción de imágenes relativas a las poblaciones indígenas. En efecto, eran producidas en gran parte de los casos en la disputa por el control de las poblaciones indígenas. Triunfos y fracasos que terminaban por dirimirse en el terreno legal, haciendo de la legislación un campo de disputa político-cultural.

La corona también debía desarrollar una estrategia de defensa y ocupación de la frontera. Hasta el siglo XVIII, la empresa conquistadora en América se había llevado a cabo a través de la fundación de ciudades. Compuestas de población básicamente «española», las ciudades constituían los centros desde los cuales se organizaba la «conquista militar» a través de «entradas» hacia los hinterlands «infieles». Sobre todo desde mediados del siglo XVI comienza a desarrollarse paralelamente la llamada «conquista espiritual» de estos espacios de frontera o «infieles», en general, a cargo de las órdenes religiosas regulares. Esta segunda forma de conquista había sido una estrategia esencial de la Corona para limitar el control del sector conquistador y había recibido especial apoyo de la Santa Sede. Como producto de estas estrategias de conquista, el «territorio colonial» era discontinuo y sumamente inestable, particularmente en las vulnerables «zonas de frontera» 10 .

La sobreexplotación de la población indígena era otro emergente de esta situación anómica. Las actitudes hacia estas poblaciones eran congruentes con determinadas formas de concebir la sociedad. Nociones estáticas como la de «honor» eran el basamento de esta sociedad estamental de Antiguo Régimen, en la que por otra parte la pertenencia estaba definida en términos parentales. Tal visión estática de la sociedad era congruente con una acendrada política de castas o en otras palabras, de «segregación racial».

tos viscerales con el clero «estatista» alineado con doctrinas como el jansenismo. Pero las redes clientelares que los jesuitas habían formado en las ciudades, particularmente en Buenos Aires permitían a los jesuitas hacerse de lugares privilegiados y tomar ventaja en las disputas. Sobre el tema Chiaramonte, José Carlos: La ilustración en el Río de la Plata. Cultura eclesiástica y cultura laica durante el virreinato. Buenos Aires, Ed. Punto Sur, 1989. En lo referente a las disputas entre cabildos y diocesis se encuentran buenos ejemplos para el caso del Río de la Plata en: Garavaglia, Juan Carlos: «El teatro del Poder: Ceremonias, tensiones y conflictos en el Estado Colonial», en Boletín del Instituto de Historia Argentina y Americana «Dr. Emilio Ravignani» ${ }^{\circ}$ 3, V. 14, 1996, pp. 7-30.

10 Sobre el problema de la frontera en América existe abundante bibliografía imposible de citar aquí. Para el período colonial desde un punto de vista global puede consultarse LázARo ÁvILA, Carlos: Las fronteras de América y los «flandes indianos». Madrid, CSIC, 1997. Para el caso del Tucumán Colonial VITAR, Beatriz: Guerra y misiones en la frontera chaqueña del Tucumán (17001767). Madrid, C.S.I.C, 1997. Y en el Paraguay, HAubERT, Maxime: «Jesuitas, indios y fronteras coloniales en los siglos XVII y XVIII: algunas notas sobre las reducciones del Paraguay, su formación y su destrucción final». Folia Histórica del Nordeste, 10, Resistencia, 1991.

R. I., $1999, \mathrm{n}^{\circ} 217$ 


\section{EL PARADIGMA SEGREGACIONISTA}

Una sociedad estamentaria como la de Antiguo Régimen se regía de acuerdo a categorías sociales estáticas, una visión cristalizada de la estructura social y de sus jerarquías internas. Este sería el modelo de sociedad que se proyectaría a las colonias. Pero dada la realidad multiétnica americana, no podía codificarse sino en la sintaxis racial de la política indigenista de segregación.

La acendrada política dualista de las dos repúblicas, tiene algunas formulaciones difusas a principios del siglo XVI. Por cierto era un debate inextricablemente unido a la discusión sobre la condición y la noción misma del «Indio», y como sabemos, ésta tuvo muchas idas y vueltas, ensayos fallidos y directivas incumplidas. No es hasta fines del siglo XVI en que esta política comienza a aplicarse sistemáticamente en Perú y Mesoamérica, con el objetivo de definir un espacio indígena separado y con derechos civiles especiales.

A fines del siglo XVI se instalaron congregaciones en Mesoamérica y reducciones en el Perú en gran escala, medidas favorables a la corona sobre todo desde un punto de vista económico, pues le permitía desplazar a los encomenderos y tasar a la problación indígena en forma directa para el tributo.

Esta política además de instituir la condición del «Indio», afirmaba la exclusión de los no-indios. Las reducciones se instituían como reservorios de pureza étnica, pues intentaban proteger a la población indígena de las mezclas espúreas ${ }^{11}$. Ciertamente, el mestizaje al implicar la disolución de los límites etno-sociales, era visto como un riesgo, una amenaza para la posición social de las capas superiores de esta sociedad entendida en términos estáticos. Permanecer en condición de «pureza» aunque fuera subordinada conservaba prestigio. Dice Mörner:

«Bien se ve que el indio puro no se consideraba 'vil'. A diferencia de los mestizos, el grupo intermedio principal, los indios constituían un grupo de hecho enormemente distanciado de las capas superior de la sociedad. Por consiguiente, estas capas no tenían por qué oponerse a que se adjudicara al indio una condición teórica y legal más o menos halagadora.. Al mantener su integridad, la capa india podía continuar ejerciendo la función que le había sido adjudicada en el siglo XVI de clase tributaria y de trabajadores honestos» ${ }^{12}$.

11 Las leyes de segregación fueron incluidas en la Recopilación de Leyes de los Reinos de Las Indias en 1680 con explícita prohibición de residencia de no-indígenas en pueblos Indios. La permanencia en los pueblos podía extenderse a lo sumo por tres días. MÖRNER, Magnus: «¿Separación o Integración? En torno del debate diociochesco sobre los principios de la política indigenista en Hispano-América.» Journal Societé des Americanistes, LIV, 1, 1965, p. 31-45; MóRNER, Magnus: «The Theory and Practice of Racial Segration in Colonial Spanish America.» Actas del Congreso Internacional de Americanistas 32, pp. 708-714, 1956.

12 MÖRNER 1965 [11], p. 34.

R. I., $1999, \mathrm{n}^{\circ} 217$ 
Las poblaciones nativas quedaban de esta forma encerradas en los límites de una situación colonial subordinada, aunque con el «privilegio de la pureza» ${ }^{13}$.

Sin embargo, el principio de segregación residencial era constantemente violado. La declinación poblacional en los pueblos de indios y los movimientos migratorios eran inevitables y por tanto lo era también el aumento del número de no-indígenas (blancos y medias castas) dentro y cerca de los pueblos. La Corona se enfrentaba a un voluminoso incremento de la población mestiza, para la cual no había una legislación específica, ni categorías capaces de delimitar su status. Como observa Mórner, las leyes de separación residencial convivían con las de libertad de matrimonio hispano-indígena, sin que se percibiese la contradicción inherente. La legislación del parentesco, buscaba «evitar matrimonios desiguales» ${ }^{14}$.

La política misional había demostrado ser la más efectiva en el control de poblaciones indígenas de tierras bajas con escaso grado de centralización política. La idea de segregar a estos «otros» en una «República de Indios», aunque estrictamente impracticable, constituía por lo menos una directriz. Las primeras reducciones o pueblos de Indios databan de fines del siglo XVI y respondían al objetivo de reconcentrar población indígena dispersa para su tasación tributaria. La política reduccional de la «República de Indios» fracasó en sus primeras aplicaciones altoperuanas, sin embargo resultó ser eficaz entre poblaciones semisedentarias de tierras bajas. De ella estaban encargadas en gran medida las ordenes religiosas, particularmente franciscanos y jesuitas.

Las misiones constituían una estrategia de asimilación de singulares características. Encerraban la paradoja de asimilar en el marco de una política segregacionista, cuando no eran meramente instrumentos para la explotación indígena. $\mathrm{El}$ «Indio de reducción» era, por otra parte, una categoría a mitad de camino entre el salvajismo y la civilización, entre la infidelidad y la fe. Como quiera que sea, las reducciones constituían espacios para la resignificación de identidades étnicas, pues con frecuencia reagrupaban individuos y grupos de diferentes filiaciones étnicas. Como ha subrayado David Sweet, este modelo tenía a lo largo de la

13 Sobre la construcción de la categoría «Indio» en el marco de la situación colonial puede verse BONFIL BATALLA, Guillerno: «El concepto de indio en América; una categoría de la situación colonial», en: Identidad y Pluralismo cultural en América Latina. Univ. de Puerto Rico. CEHASS/ED, 1992.

14 «Podemos por lo tanto notar que las leyes de separación que se habían formado durante las segunda mitad del siglo XVI , cuando la 'sociedad de castas' apenas se había establecido aún, parecían, en cierto modo, justificadas desde una perspectiva más amplia durante el siglo XVIII con sus fuertes prejuicios etno-sociales. Mientras que, durante los siglos anteriores, la libertad de contraer matrimonios inter-raciales había coexistido con las leyes de separación residencial casi sin notarse la contradicción inherente, ahora los dos problemas llegaron a identificarse». MÓRNER 1965 [11] p. 34 .

R. I., $1999, \mathrm{n}^{\circ} 217$ 
extensión americana, componentes relativos de constreñimiento y opcionalidad para los actores idígenas ${ }^{15}$.

Por un lado, las misiones habían modificado las nociones de espacialidad y temporalidad de las cosmovisiones aborígenes reduciéndolas al ritmo de trabajo homogéneo de economías excedentarias. Pero por otra parte, en muchos casos, aseguraron la supervivencia de las lenguas y ciertas prácticas tradicionales que no atentaban contra el «buen orden cristiano». Como dijimos, las misiones junto con las ciudades, eran los núcleos organizadores de la conquista y las bases de un modelo territorial discontinuo.

Las Reducciones guaraníes del Paraguay constituyen quizá uno de los casos más representativos de la política indigenista de segregación, pues aplicaron estrictamente el principio de separación y lo utilizaron constantemente como argumento legal.

\subsection{Las reducciones guaraníes}

Herbert Bolton definía a las misiones como instituciones coloniales de frontera, claves para el dominio español en Ameríca. «afirmaba que tenían tres proposiciones centrales: «Convertir, Civilizar y Explotar». Esta consigna, en efecto, se corporiza en el discurso de los primeros misioneros que llegan al Paraguay a fines del siglo XVI. Y era precisamente en las zonas de frontera donde este discurso se hacía crítico. A nivel micro, la frontera constituía un complejo entramado sociocultural, una maraña de sentidos de pertenencia yuxtapuestos y dinámicos. A nivel global, las misiones constituían un importante brazo del Estado en el control de las poblaciones nativas, implicando una modalidad específica de legislación.

La llamada «Provincia Jesuítica del Paraguay» en cuya jurisdicción se encontraban las famosas reducciones guaraníes, estaba ubicada en territorios que hoy comparten «Argentina, Paraguay y Brasil, y cumplía el papel de proteger la frontera. Habían sido pensadas con el propósito de generar «barreras de contención» ante el avance de las huestes conquistadoras portuguesas (bandeirantes), de los encomenderos del Paraguay y de diversos grupos indígenas no reducidos; todos actores interesados en el reclutamiento de mano de obra indígena para encomiendas y servicios personales, cuando no simplemente de esclavos. En general, concentraban población de las diversas parcialidades dispersas en la región.

\footnotetext{
15 La experiencia indígena no ha sido suficientemente considerada por la historiografía de las Misiones. En gran parte producida por los mismos misioneros, las crónicas perpetuaban una visión infantilizadora de estas poblaciones, concebidas como incapaces de articular su propia historicidad. Un viraje de esta perspectiva puede considerarse LANGER, Erick \& Robert H. JACKSON (ed.): The New Latin American Mission History. University of Nebraska Press, 1997. En esta compilación particularmente interesante resulta el trabajo comparativo de SWEET, David: «The Ibero-American Frontier Mission in Native American History», pp. 1-48.
}

R. I., 1999, n. $^{\circ} 217$ 
Las primeras reducciones son organizadas por los jesuitas, quienes en 1610 fundan la primera de las treinta conocidas concentraciones de indios en el área ${ }^{16}$. Hacia principios del siglo XVIII y tras reiterados avatares e invasiones, deserciones, saqueos y transmigraciones- las reducciones ya conformaban un sistema económico-político relativamente autónomo, a pesar de las diferencias regionales del gran territorio que ocupaban ${ }^{17}$.

Fueron las «Ordenanzas» del visitador Alfaro las que dieron un impulso determinante a las primeras fundaciones jesuitas, definiendo el perfil de la normativa básica que regiría las reducciones. Las ordenanzas representaban puntos muy favorables a los indios, tales como la supresión de los servicios personales y la limitación de las encomiendas. Respecto de las normas de residencia, ordenaba Alfaro en 1610:

«(...) que en pueblos de indios no estén ni se reciban ningún español, ni mestizo, negro ni mulato. $\mathrm{Y}$ especialmente se entiende esto con las mujeres (...)»; «(...) mando que en contorno del pueblo de indios, ni de chácaras suyas, no puedan haber chacaras de españoles en distancia de media legua.»; «(...) se manda que ningún indio pueda sembrar para si fuera de su reducción, aunque sea en chacara de españoles $(. ..) \gg^{18}$.

La triple interdicción de residencia, intercambio sexual y trabajo era contundente, y los treinta pueblos guaraníes serían uno de los pocos casos de aplicación «purista» de estas disposiciones. Lo que Susnik ha denominado atinadamente, para el caso de las reducciones del Paraguay, «exclusivismo guaranítico», es justamente el conjunto de características que hacía de las reducciones un espacio relativamente autónomo. Por su parte, Garavaglia en su «modelo jesuítico-guaraní» demuestra que muchos elementos de autonomía eran coherentes con las tradiciones nativas. Entre ellos, el mantenimiento de la lengua quizá sea el más notable junto con la conservación de sistemas económico-políticos de reciprocidad. Además, la per-

16 Si bien los jesuitas ya se encontraban en la región desde fines del siglo XVI, no habían ejecutado un programa reduccional sistemático, a diferencia de los franciscanos cuya empresa estaba bastante consolidada. NECKER, Louis: Indios guaranies y chamanes franciscanos. Asunción, Biblioteca Paraguaya de Antropología, 1990.

17 La provincia «Paracuaria» había alimentado infinidad de historias en pro y en contra de los jesuitas. El universo idílico creado por las crónicas en torno de la vida en las reducciones desencadenó reacciones (a veces contradictorias) en el incipiente espíritu iluminista europeo del siglo XVIII. Una avalancha de elogios y condenas se descargaba sobre las misiones convirtiéndolas en el centro del debate en la política indigenista. ARMANI, Alberto: Ciudad de Dios y Ciudad del Sol. El «Estado» jesuita de los guaraníes (1609-1768). México, Fondo de Cultura Económica, 1987; Alvarez Kern, Arno: Missoes, uma utopia politica. Porto Alegre, Rio Gande do Sul, 1982.

18 Alfaro, Diego de: «Ordenanzas», en HERnÁNDEZ, Pablo: Organización social de las doctrinas guaraníes de la Compañía de Jesús. Barcelona, Gustavo Gilli editor, vol. 2, 1913, [Apendice documental] ver pp. 665-667.

R. I., $1999, \mathrm{n}^{\circ} 217$ 
manencia de instituciones de gobierno como el cabildo, que tendrían cuerpo completo de funcionarios indígenas favorecía a la autonomía política. A estos elementos se sumaría más tarde el aval de la corona para la formación de milicias guaraníes y la posesión de armas de fuego ${ }^{19}$.

Tal fue el impulso de este modelo reduccional que entre los siglos XVII y XVIII probablemente las fundaciones hayan superado el centenar en toda la Provincia Jesuítica ${ }^{20}$.

\subsection{Fisuras en el modelo dualista}

En términos un tanto esquemáticos podríamos decir, que a lo largo de los siglos XVI y XVII se produjeron dos dinámicas generalizadas y contradictorias que condicionaron la gestación de nuevas pertenencias socioculturales. Por un lado, una legislación indiana que categorizaba de manera fija la estructura social en las colonias de acuerdo a una «política de castas». Legislación que se sustentaba en nociones culturales estamentales propias de la Sociedad de Antiguo Régimen, y que operaba como instrumento de homogeneización cultural. Por otro lado, un movimiento poblador en el que espontáneamente surgían nuevas categorías socioculturales que, por su diversidad y mutabilidad no tenían lugar en la legislación. Estas últimas categorías socioculturales ponían en jaque la estructu-

19 Las armas no eran un elemento ajeno a las poblaciones guaraníes que desde antes de la conquista inclusive hacían de la práctica de las guerra entre parcialidades una forma de mantener la cohesión grupal. Sobre este punto cfr. Roulet, Florencia: La resistencia de los guaraní del Paraguay, a la conquista española (1537-1556). Posadas, Ed. universitaria, Universidad Nacional de Misiones, 1993. Sobre la formación y características del modelo de las misiones guaraníes la bibliografía puede extenderse por decenas de páginas. Se encuentran buenos esbozos en GARAVAGLIA, Juan Carlos: «Un modo de producción subsidiario: la organización económica de las comunidades guaranizadas durante los siglos XVII-XVIII en la formación regional altoperuanarioplatense», en Assadurian, C. S. (comp.): Modos de Producción en América Latina. México, Cuadernos de Pasado y Presente, 1984; GARAVAGLIA, Juan Carlos: Economía, sociedad y regiones. Buenos Aires, Ed. de la flor, 1987; SUSNIK, Branislava y Miguel CHASE-SARDI: Los indios del Paraguay. Madrid, MAPFRE, 1992; ARMANI [17] Y desde luego el ya clásico MÖRNER, Magnus: Actividades políticas y económicas de los jesuitas en el Río de la Plata. Buenos Aires, Hyspamérica, 1985. A pesar de su tono apologético son útiles las obras de Pablo HERNÁNDEZ [18] y de FURLONG, Guillermo: Misiones y sus pueblos guaranies, Buenos Aires, 1962.

20 QUERINI, Manuel: «Informe del padre Querini sobre los progresos de las misiones del Paraguay», en BRABO, Francisco Javier: Inventarios de los bienes hallados a la expulsión de los jesuitas y ocupación de sus temporalidades por decreto de Carlos III, en lo pueblos de Misiones, fundados en las márgenes del Uruguay y Paraná, en el Gran Chaco, en el país de Chiquitos y en el Mojo, cuyos territorios pertenecieron luego al Virreinato de Buenos Aires. Madrid, M. Rivadeneyra, 1872, pp.631-646. Este documento detalla la situación de la Provincia jesuítica del Paraguay hacia 1750. Querini enumera 49 reducciones en jurisdicciones de los obispados de Paraguay, Buenos Aires, Tucumán, Charcas y Santa Cruz de la Sierra. Hay que considerar que muchas de ellas habían sido trasladadas de sus sitios originarios debido a problemas típicos de «frontera» como los saqueos de diversos grupos indígenas y no-indígenas.

\section{R. I., $1999, \mathrm{n}^{\circ} 217$}


ración social estamental. Por más que las reducciones del Paraguay constituyeran una excepción, la separación residencial de indígenas y no-indígenas no se cumplía en la mayor parte de los $\operatorname{casos}^{21}$ : En cuanto a lo que globalmente podría definirse como «mundo español», hasta las diferencias generacionales constituían un argumento para la exclusión de algunos sectores ${ }^{22}$.

La Corona debía ahora enfrentarse a una compleja realidad multiétnica, en la que las divisiones tradicionales - indio/blanco/negro- comenzaban a percibirse anacrónicas. En efecto, la inercia de las dinámicas locales obligó a la Corona a rediseñar su política administrativa en el siglo XVIII y si bien estas reformas eran de carácter económico-político, tendrían grandes implicancias en la política indiana en la medida que replanteaban las nociones de Estado y de sociedad tradicionales. Nociones fundamentales del Antiguo Régimen se veían amenazadas en esta transición. Los principios del Antiguo Régimen comenzaban a ceder frente a la lenta germinación de una concepción económica utilitarista y una ideología política contractualista. Así, por ejemplo, nociones como la de «honor», tradicionalmente ligada a la nobleza y la sangre, ahora comienza a ser asociada a nociones más móviles y «burguesas» como la de trabajo manual y trabajo de la tierra. $\mathrm{La}$ «honra de la sangre» comenzaba a verse erosionada por la «honra de la riqueza y el trabajo». La apología del ocio se veía desplazada por la revaloración del trabajo manual y del comercio ${ }^{23}$.

Era inevitable que hacia fines del siglo XVIII las medidas comenzaran a modular un tono modernista inspirado en el espíritu de la época. Los borbones eran sensibles a las influencias del pensamiento ilustrado de fines del siglo XVIII y se rodearon de intelectuales alineados en esta corriente ${ }^{24}$.

El Estado español experimentaba en su seno la contradicción de tendencias conservadoras y transformadoras. El siglo XVIII es particularmente efervescente en torno de la discusión sobre cuál debía ser la injerencia del Estado en los

21 Aún en el caso de las reducciones del Paraguay hay testimonios de fugas a las haciendas por parte de algunos guaraníes que preferían conchavarse antes que permanecer bajo el duro régimen de explotación de las reducciones. Para el período jesuita cfr. CARDIEL, José: «Breve Relación de las Misiones del Paraguay», en HeRnáNDEZ [18] Apéndice documental: № 47, pp. 514-614. Para el período posterior a la expulsión cfr. SUSNIK, Branislava: El Indio Colonial del Paraguay. Asunción, Museo Etnográfico «Andrés Barbero», 1965-1971; WHIGHAM, Thomas: «Paraguay`s Pueblos de indios: echoes of a Missionary», en: LANGER, E. \& JACKSON R. (eds.): The New Latin American Mission History. Univ. of Nebraska Press, 1997.

22 LOCKHART [6].

23 Guillamón AlvareZ, Javier: Honor y honra en la España del siglo XVIII. Madrid, Departamento de Historia Moderna, Fac. de Geografía e Historia, Universidad Complutense, 1981.

24 Es el caso de Jovellanos y Campomanes que, entre otros, fueron ideólogos de gran influencia. A propósito de las contradicciones inherentes al proceso «Modernización» en el Río de la Plata puede consultarse Chiaramonte, quien focaliza especialmente en el problema de los contenidos en la enseñanza hasta entonces controlada por los jesuitas, y sus disputas internas. CHIARAMONTE, José Carlos: Ciudades, provincias, estados: orígenes de la Nación Argentina (1800-1846). Buenos Aires, Ariel, 1997.

R. I., 1999, n. $^{\circ} 217$ 
asuntos religiosos. En este sentido, los debates en materia de «teoría moral» tenían carácter político y apuntalaban el proceso de reconfiguración de la imagen del Estado. Por su parte, las políticas indigenistas se encontraban sumidas en permanentes ambigüedades y contradicciones; como tratando de conciliar tendencias conservadoras y tendencias innovadoras. Así, combinaban ideas de libertad e igualdad, con tendencias a la sujeción y la jerarquización estática de la población indígena.

La expulsión de los jesuitas constituyó un hito central en la política reformista de los borbones. Fue un acontecimiento que por el alcance que tuvo en toda América conllevó no sólo una redefinición de la relación metropoli-colonia sino también, especialmente, una reformulación de la política indígena.

\section{EL NUEVO IMAGINARIO ASIMILACIONISTA}

El proceso de transición hacia una sociedad moderna significó la autonomización de las actividades de la vida social en esferas diferenciadas. Así es como la dimensión político-económica comenzó a constituir un «campo con reglas propias» y a diferenciarse de la dimensión religiosa. Se perfilaba una secularización de la sociedad basada en el principio antropocéntrico de la razón. En el caso de España, este movimiento se consolidaba por medio del activismo de las «Sociedades Económicas», que hacían del trabajo, el comercio y la ciencia, palabras resonantes del discurso racionalista de la reforma. La razón, junto a la libertad y la igualdad (al menos en el sentido de equidad), eran principios centrales de una prédica universalista que poco a poco resquebrajaba los valores tradicionales. $\mathrm{Al}$ ser éste un modelo universal era pasible de ser asimilado por y contagiado a quienes no lo poseían ${ }^{25}$.

En este marco se produce un viraje de la política indigenista. Según Mórner en el siglo XVIII las reducciones en el Río de la Plata ya no poseían el mismo papel defensivo que tuvieran en el siglo anterior. Por otra parte, el monopolio de la Compañía de Jesús hacía verlas más bien como un obstáculo al control directo de la corona.

\subsection{Las reformas de Bucareli}

«Igual desdicha experimentaban en el vestuario y las mujeres con tal extremo, que es imposible demostrarlo sin faltar a la modestia, no pudiéndose

25 ANES, Gonzalo: Economía e ilustración en la España del siglo XVIII. Madrid, Ariel, 1969; ANES, Gonzalo: La corona y la América del siglo de las luces. Madrid, Marcial Pons. Asociación Francisco Lopez de Gomara, s/a.

R. I., 1999, n. ${ }^{\circ} 217$ 
atribuir a desidia ni a su voluntad, por que los trages que les hice repartirse los vistieron luego estimándolo y agradeciéndolo.

Semejantes tiranías, y la cortedad de sus habitaciones, ocasionaban muchas ofensas a Dios y frecuentes enfermedades y epidemias, en que perecía crecido número de aquellos pobres, a cuyas expensas lograban los de la Compañía engrandecer su poder, disfrutando toda la sustancia de este imperio, que así lo titulaban comúnmente».

Francisco de Bucareli y Ursua, 1768

Don Francisco de Paula Bucareli y Ursua fue el encargado de efectuar la expulsión de los jesuitas en el Río de la Plata en el año 1767. Por ese entonces, ocupaba el cargo de gobernador de Buenos Aires, y su postura antijesuita había generado no pocos resquemores entre los vecinos de la ciudad. En 1768, Bucareli concretó la expulsión en los treinta pueblos guaraníes del Paraná y el Uruguay en un itinerario que tendría mucha resonancia ${ }^{26}$.

$\mathrm{Al}$ ejecutar su plan, Bucareli parecía ser consciente de la lógica que debía regir el intercambio con los líderes guaraníes. Es conocido el episodio en el que convocó a los caciques y corregidores de los treinta pueblos en la ciudad de Buenos Aires, donde los agasajó haciéndoles participar de ceremonias y otorgándoles privilegios y regalos en nombre del Rey. Si bien muchas de estas concesiones se ajustaban a la legislación indiana, algunas como el privilegio para los líderes, de llamarse Don; o para sus hijos, de acceder al sacerdocio, eran completamente nuevos entre los guaraníes. De este modo, Bucareli inició un vínculo de carácter «reciprocitario» que le permitiría lograr consenso en el nuevo gobierno. A su vez, estos resignificarían las relaciones con el mundo blanco ${ }^{27}$.

Puede decirse que con esta operación, Bucareli instauró el control directo de la corona en un sitio donde por mucho tiempo había tenido escasa injerencia. Completada la expulsión en los pueblos, Bucareli promulgó una serie de disposiciones que habrían de regir su gobierno de allí en más. Luego de reemplazar a los jesuitas con curas de nuevas órdenes, instaló gobernadores y administradores españoles. Mantuvo el régimen económico de explotación colectiva (tupambaé),

26 Sobre el itinerario de la Expulsión y su significado puede consultarse GoNZALEZ, Julio Cesar: «Notas para una historia de los treinta pueblos de Misiones. El proceso de expulsión de los jesuitas (1768)». Sociedad de Historia Argentina. Anuario. (separata), Buenos Aires, 1942; HERNANDEZ [18]; WILDE, Guillermo: «La actitud guaraní ante la expulsión de los jesuitas: Ritualidad, Reciprocidad y Espacio Social», en Memoria Americana 8. Cuadernos de Etnohistoria, Buenos Aires, Instituto de Ciencias Antropológicas, Facultad de Filosofía y Letras, Universidad de Buenos Aires, 1999 (en prensa)

27 En WILDE, Guillermo [26] dedicamos especial atención a los mecanismos simbólicos instrumentados en el «proceso de expulsión» de los pueblos guaraníes, en el cual los universos culturales indígena y español encontraron el punto de intersección para una transición pacífica al nuevo régimen.

R. I., 1999, n. ${ }^{\circ} 217$ 
al igual que los cabildos indígenas. Los administradores particulares se ocuparían de controlar los bienes comunales junto con el corregidor y el mayordomo indígenas $^{28}$. De esta forma, introducía una marcada separación entre las competencias temporales y las espirituales en la que los nuevos curas - franciscanos, mercedarios y dominicos - se encargarían exclusivamente de los asuntos religio$\operatorname{sos}^{29}$. Como ya hemos visto, las misiones del Paraguay constituían hasta entonces un paradigma del segregacionismo en la política indigenista. Los jesuitas celosamente habían defendido esta política desde las primeras fundaciones, promoviendo en sus crónicas imágenes infantilizadas de los guaraníes ${ }^{30}$. El gobierno instaurado en los pueblos después de la expulsión, si bien no erradicaba en forma definitiva esta visión paternalista, buscaba imponer en los pueblos una nueva cosmovisión socioeconómica basada en las ideas ilustradas de igualdad y libertad.

Las disposiciones que recayeron sobre los pueblos fueron conocidas como «Ordenanzas de Bucareli», aunque estrictamente fueron tres conjuntos de directivas promulgados sucesivamente: la Instrucción, la Adición y las Ordenanzas de Comercio. Estas disposiciones se erigían en «fundadoras» de una nueva relación hispano-indígena, de la cual se infería una redefinición del Estado y de la política referida a la población nativa. La imagen del Indio debía ser congruente con la política racionalista y asimiladora que trataba de instrumentarse, por eso, resaltaba las capacidades inherentes al Indio para la asimilación. De hecho, la tónica general de las disposiciones de Bucareli, especialmente la «Instrucción», era asimilacionista, ya por la exhortación a introducir valores culturales españoles (Instrucción y Adición) como por el fomento de modelos económicos y políticos peninsulares (Ordenanzas de comercio).

En general, las reformas de Bucareli alentaron la adopción de hábitos y estilos de vida españoles por parte de los indígenas. Con un visionario espíritu asimilacionista, el gobernador afirmaba: «Los naturales parecen dóciles y humildes, y su comprehensión como la de otras naciones de Europa(...)» ${ }^{31}$. Y en otro lugar subraya que debe cuidarse en «aplicar todos los medios conducentes a que se extinga la odiosa separación que hasta ahora se ha conservado entre los indios y blancos» ${ }^{32}$.

28 MAEDER, Ernesto: Misiones del Paraguay, conflicto y disolución de la sociedad guaraní. Madrid, MAPFRE, 1992; POENITZ, Edgar y Alfredo: Misiones, provincia guaranítica. Defensa y disolución (1768-1830). Posadas, Ed. Universitaria, Universidad Nacional de Misiones, 1993.

29 Esta separación tajante entre lo temporal y lo espiritual traslucía el largo conflicto entre Iglesia y Estado, y en el contexto específico de las reducciones guaraníes adquiría un significado particular, pues tal división de competencias no había existido durante más de un siglo y medio. Como resultado los años posteriores a la expulsión se caracterizan por la constante trangresión de esta separación por parte de los administradores y los nuevos curas.

30 El calificativo «Niños sin barba» era común en la prédica de misioneros paraguayos y posteriormente fue adopatada por algunos funcionarios civiles familiarizados con las crónicas.

31 BRABO [31], p. 197.

32 BRABo [31], p. 208

R. I., 1999, n. ${ }^{\circ} 217$ 
A nuestro modo de ver, la «Instrucción» constituye un esbozo incisivo y bastante temprano de una nueva política de asimilación que más tarde se profundizaría. No se trata de un simple ejemplo perdido en el mar legislativo finisecular. Por el contrario representa un punto de quiebre con la concepción previa de Estado.

La política indígena, aunque fue sólo una dimensión de la reforma, condensaba la imagen misma del Estado. Justamente, el viraje de política debía producirse sobre todo allí donde tuviera mayor resonancia, esto es, donde los «libelos» de la época clavaban una filosa astilla difundiendo la existencia de un estado dentro del estado. Los jesuitas habían logrado monopolizar las relaciones hispano-guaraníes a través de un modelo reduccional que funcionaba en forma de red, y esto era visto como una amenaza para el sector conquistador.

Frente a esta situación, las ordenanzas expresaban una imagen de Estado secularizado, es decir, con esferas políticas claramente definidas. Y a propósito de este punto, la Instrucción pretendía establecer de forma tajante las competencias eclesiásticas y las competencias civiles ${ }^{33}$. Separación que comúnmente se erosionaba en el nivel de las prácticas locales (antes, durante y después de Bucareli). Pero este corpus legal, además, intentaba construir al «otro» a partir de nociones universalizadas de humanidad.

En la Instrucción, Bucareli define sus objetivos principales. El primero, «radicar a estos indios en un verdadero conocimiento de los adorables misterios de nuestra fe». Y el segundo, «...proporcionar a estos indios aquellos beneficios y conveniencias temporales que se adquieren por los medios de la civilidad, de la cultura y del comercio» ${ }^{34}$.

Como veremos, la tríada civilidad, cultura y comercio se encuentra en la base del discurso asimilacionista de Bucareli, y naturaliza nociones propias de la ilustración. No es siempre clara la distinción entre estas nociones; es común verlas desplazarse y superponerse para definir los límites de la totalidad sociocultural difusa, a mitad de camino entre una concepción de Antiguo Régimen y una de Estado moderno.

La noción de civilidad es central en la Instrucción. Aparece ligada a la normatividad cultural de la vestimenta, la residencia y la sexualidad; como también a justificaciones culturales de la jerarquización socio-política.

En ella queda claro que la política indígena debía ser también una política lingüística. Los indios debían asimilarse incorporando el idioma castellano y todas las prácticas y representaciones asociadas al modo de vida español. En este sentido fue útil la implementación de un régimen de enseñanza de la lengua castellana a través de escuelas con maestros laicos y la prohibición del uso del guaraní

33 Los párrocos no debían «...mezclarse en asunto diverso de su ministerio, por no haberles quedado otra ocupación, que la concerniente al bien espiritual de las almas». BRABO [ ], p. 200.

34 BRABO [31], p. 200. 
en ese contexto. Esto permitiría también en las palabras del gobernador, superar el aislamiento en el que se encontraban sumidos los pueblos. Debía imponerse la enseñanza del castellano, para el mejor «trato civil e instrucción cristiana».

Ordena la instalación de escuelas para la educación de «indios pequeños», donde aprenderán doctrina cristiana, leer, escribir y contar en nuestro idioma. Y quedaba prohibido hablar el guaraní en las clases.

\begin{abstract}
«...conceptúo que es la base fundamental el introducir el uso de nuestro propio idioma. Este es una de los medios más eficaces para desterrarles la rusticidad; como que; uniformándonos en el lenguaje, serán estos indios generalmente comunicables, y percibirán con más proporción el civilizado estilo de que usamos, prudente y sólido sistema que también se ha observado por otras naciones políticas, con el conocimiento de que, al mismo paso que se introduce en los súbditos el uso del idioma propio de un Príncipe, se les asegura más fácilmente en el afecto, veneración y obediencia debida al soberano» ${ }^{35}$.
\end{abstract}

Es notable el modo como el discurso de Bucareli articula la pertenencia sociocultural con el uso del lenguaje. En este sentido, era ante todo «el idioma» el que viabilizaría la asimilación cultural. Aunque el concepto de «aculturación» tiene aparición muy posterior, vemos en este discurso una utilización muy temprana del mismo. La función de la escuela en este punto era clave y sorprende que Bucareli no dudara, como otros funcionarios de la época, de la capacidad indígena para aprender; o en todo caso resulta raro que la admita abiertamente cuando dice que se les enseñe «...en los mismos términos que se practica en nuestras escuelas» ${ }^{36}$. Esta tarea quedaría a cargo del cura y el compañero, aunque más tarde instala maestros.

En cuanto a la vestimenta: «(...) se hace preciso introducir en estas gentes aquellas imaginaciones que las pueden conducir a un virtuoso y moderado deseo de usar de un vestuario decoroso y decente, desterrando totalmente la desnudez, que no es efecto de la virtud, sino de la rusticidad» ${ }^{37}$.

La vestimenta debía corresponder al rango que ocupaban las personas en la estructura social:

«(...) los dirija a conseguir, no solo el abandono del vestido mujeril y el debido uso de otro más honesto y propio de su sexo sino también a que los demás indios se visten y calcen a correspondencia de sus empleos y graduación, prohibiendo que compren ridículos vestidos que, con titulo de danzantes y cabildantes solo servían para consumir inútilmente a estos miserables una gran

\footnotetext{
35 BRABO [31], p. 201.

36 Ibidem.

37 BRABO [31], p. 201.
}

R. I., 1999, n. 217 
parte de su caudal y sustancia y respecto de los existentes que arbitre destinas más conformes de con la civilidad» ${ }^{38}$.

Como puede verse, la noción de civilidad iba asociada a la construcción de una jerarquización social e implícitamente una división sexual de los roles político-sociales. Afirmaba Bucareli:

«...considerando que en las repúblicas civilizadas debe haber diversa graduación de personas, a proporción de los ministerios que ejercen, y (...) sean tratadas con aquellas honras que se deben a sus empleos» ${ }^{39}$.

Ordena que se trate con distinción en público como en privado, a caciques, corregidores y todos los indios que fuesen jueces y ocuparan algún empleo honorífico. Promovía el cumplimiento de la precedencia respecto de la ocupación de lugares y adquisición de símbolos de prestigio tales como la vara y el bastón. Estos eran valores de una sociedad estamental. Ciertamente, Bucareli se guiaba por principios de «honor» y prestigio propios de su cultura peninsular que consideraba universales, o al menos, universalizables. Este es un ejemplo de la ambigüedad de un discurso oficial en transición.

Así por ejemplo, síntomas de incivilidad serían la «...indecencia con que se tratan en sus casas, asistiendo distintas familias en una sola y estrecha habitación, faltando por lo mismo aquellas reglas de la honestidad que se debe a la diversidad de sexos.... ${ }^{40}$.

Subyacían a estas exhortaciones modelos naturalizados de comportamiento sexual y claro está, un modelo de parentesco coherente con patrones residenciales preestablecidos. En consecuencia, ordena reducir las viviendas «...para que, viviendo las familias con separación, puedan guardar, como racionales, las leyes de la honestidad y policía ${ }^{41}$.

Respecto de las alianzas matrimoniales Bucareli señala que éstas deben contribuir a diluir la separación entre indios y españoles. Se basa en la ley de Indias que autoriza «...la libertad que los indios deben tener en los casamientos con españoles, auxiliará Ud estos sagrados vínculos siempre que se proporcionen, para que los indios acaben de comprender la reciproca unión que debe establecerse» ${ }^{42}$.

No obstante, el estado de civilidad no era posible sin cultura y sin comercio. ¿Cómo se articulaban estas otras dos nociones de la tríada?

\footnotetext{
38 BRABO [31], p. 202.

39 BRABO [31], p. 201.

40 BRABO [31], p. 202.

41 Ibidem.

42 BRABO [31], p. 208.
} 
El sentido que recibe la noción de cultura en la Instrucción está vinculado al cultivo de la tierra, es decir, al trabajo. Un valor que el Estado en transición comenzaba a concebir como honroso.

«No omitiéndose, finalmente, diligencia alguna de introducir en ellos aquella honesta y loable ambición que, desterrando de las repúblicas el pernicioso vicio de la ociosidad, las hace opulentas, principalmente, siendo estas tales, que su misma fertilidad estimula el trabajo en el seguro logro que promete $(. .).)^{43}$.

Bucareli exhorta a los gobernadores a convencer a los guaraníes del beneficio del trabajo para el sustento familiar y la abundancia. La venta de frutos adquiridos mediante la «cultura» recibiría a su vez el premio de la honra ${ }^{44}$. Este es uno de los puntos en que la noción —o mejor, la práctica — de la «cultura» se entrelaza con una de las variables de la noción de civilidad, en tanto que aquel que cultiva se beneficia del ascenso y las distinciones inherentes a la condición de civilidad.

$\mathrm{Si}$ bien el comercio es motivo de disposiciones extensas en la ordenanza de comercio de 1770, en la Instrucción se imprimen sus postulados básicos.

«Entre los medios que pueden conducir cualquier república a una completa felicidad, siempre es más eficaz que la introducción del comercio, porque enriquece los pueblos y civiliza las naciones, y para que los indios de estos pueblos logren estos conocidos bienes» ${ }^{45}$.

Sin embargo, el comercio no era posible sin una previa acumulación de los productos de la «industria» y el «trabajo». A la idea de la acumulación parece referirse Bucareli cuando afirma que «(...) toda la felicidad de estos pueblos y de cualquier otro país consiste en la abundancia de víveres necesarios a la conservación» ${ }^{46}$.

Un comercio pleno tampoco era posible sin la introducción de valores de cambio, y este era un punto particularmente crítico en una región donde circulaba escasa moneda y gran parte de los intercambios se realizaban por medio de trueque.

43 BRABO [31], p. 203.

44 «...y que aquel que hiciese más servicio al publico en este fructuoso trabajo, se hará tanto más digno de las honras y empleos para que SM se ha servido habilitarlos» BRABO, [31], p. 203. Es interesante observar cómo el concepto de «honor» tan fuertemente vinculado a la estructura estamental feudal comienza a vincularse al trabajo. Se transforma en un bien adquirible. Sobre la resignificación del concepto de honor cfr. GuILlamón Alvarez [23]. Otro tanto puede decirse de la idea del comercio, actividad tradicionalmente concebida como vil, pero que en la América colonial del siglo XVII en adelante era tan común que ni los «hidalgos» eran ajenos a tratos y contratos de índole diversa.

45 BRABO [31], p. 206.

46 BRABO [31], p. 204

R. I., 1999, n. $^{\circ} 217$ 
La pregonada libertad del comercio se veía limitada por este factor y por una visión infantilizada la población indígena. Decía Bucareli:

«Y aunque es indisputablemente cierto que en la libertad consiste la alma del comercio [...] con todo, como estos no se hallen por ahora en aptitud de comprender la legitima reputación de sus géneros ni tampoco alcancen el justo precio de los que necesitan para su uso, no podrán, ínterin no tienen esta precisa inteligencia, vender ni contratar a su arbitrio, pues faltaría la igualdad del comercio y estarían expuestos a ser perjudicados notablemente» ${ }^{47}$.

Aunque en términos un tanto ambiguos, Bucareli introducía una incipiente noción utilitarista:

«Siendo innegablemente cierto que entre los efectos comerciables, unos se deben reputar superfluos, atendido el estado miserable de estos indios, y otros sumamente nocivos y perjudiciales, como son aguardiente, vino y otras bebidas fuertes, por lo mismo, encargo a Ud,. que no consienta que los frutos de estos pueblos se permuten por géneros que a los indios no les sean útiles y precisamente necesarios para su decente vestido, y mucho menos por aguardiente $u$ otra bebida, no acostumbrados estos indios alguna, pues de introducirse aquellas, sería dar lugar a los graves desordenes y perturbaciones que ocasionan» ${ }^{48}$.

Tres meses al año estaban autorizados los comerciantes a permanecer en los pueblos. Pero uno de los aspectos que con mayor fuerza atentan contra el modelo previo es la autorización de residencia de labradores españoles en los pueblos, a los cuales se les asignarían tierras para que con su trabajo sirvieran de ejemplo a los indígenas. Esta suerte de «asimilación por contagio» está ligada implícitamente a la posibilidad universal de adquirir conocimientos por medio de la enseñanza, propia de la prédica ilustrada. Y en ella, la lengua cumplía un rol central ${ }^{49}$.

«...el establecimiento de algunos españoles en estos pueblos (...) para facilitar el «... mejor el comercio recíproco y por este medio y el de la comunicación se consiga la civilidad que se desea en estas gentes, pero deberá UD in-

47 BRABO [31], p. 206.

48 BRABO [31], p. 207.

49 Este «contagio positivo» del «buen orden» asocia en algunos documentos de la época la noción de civilidad con la de limpieza. De allí que infieles, portugueses, indígenas y españoles desertores constituían peligros de contaminación. Para una profundización sobre la relación entre contaminación y orden social constituye un referente ineludible la obra de Mary Douglas: Pureza y Peligro. Madrid, Siglo XXI, 1991.

R. I., $1999, \mathrm{n}^{\circ} 217$ 
formarse de sus procedimientos, para no permitir esta residencia a los que sus operaciones no estén ajustadas a más muy cristianas y ejemplares máximas» ${ }^{50}$.

Dice que se les asignará tierras para que labren, haciéndoles entender que están «obligados a conservar con los indios aquella recíproca paz que exigen las leyes de la humana civilidad ${ }^{51}$. Podemos observar que en este punto se articulan las nociones comercio, cultura y civilidad, en tanto que el cultivo fomenta el comercio que a su vez asegura la comunicabilidad propia de la civilidad, en este caso asociada a la «recíproca paz».

Finalmente, este modelo con sus contradicciones inherentes, se implementa de manera tortuosa en los pueblos guaraníes. Bucareli insiste en varios párrafos en que debe procederse con «suavidad y templanza», es decir, por consenso y consentimiento. En este sentido, es significativo que mantenga los empleos de justicia a los mismos guaraníes, suprimiendo las penas más severas y aconsejando a los funcionarios españoles evitar el «horror del castigo». De esta manera otorga un marco legal y jurídico al conjunto de reformas, nuevamente aplicando un principio racionalista universal según el cual: «(...) la igualdad del premio y del castigo consiste el equilibrio de la justicia y buen gobierno de las repúblicas» ${ }^{52}$.

Las ordenanzas fueron las fundadoras de un debate que se prolongaría por los 40 años subsiguientes, en torno de la liberación del régimen de explotación comunal. En sus contradicciones inherentes y desplazamientos lingüísticos se condensaba la figura de un Estado y una sociedad en proceso de transición.

\section{EPÍlOGO}

«PRIMERO: todos los naturales de Misiones son libres, gozarán de sus propiedades y podrán disponer de ellas como mejor les acomode, como no sea atentando contra sus semejantes.» (...)

«CUARTO: Respecto a haberse declarado en todo iguales a los españoles que hemos tenido la gloria de nacer en suelo americano, les habilito para todos los empleos civiles, políticos, militares y eclesiásticos, debiendo recaer en ellos como en nostoros los empleos del gobierno, milicia y administración de sus pueblos».

Manuel Belgrano, Reglamento para el Régimen político y administrativo de los pueblos de Misiones. 1810.

50 BRABo [31], p. 208.

51 Ibidem.

52 BRABO [31], p. 209.

R. I., $1999, \mathrm{n}^{\circ} 217$ 
Las «ordenanzas» de Bucareli, aunque fueron ineficaces desde un punto de vista administrativo - ya por sus inherentes contradicciones, o por su aplicación incompleta, o por el grado de corruptibilidad de los funcionarios, clérigos y líderes indígenas- marcaron el inicio de una nueva etapa en las relaciones hispanoguaraníes.

En 1770 asumió como gobernador José de Vertiz, quien desconfiando de la gestión de su antecesor relevó la situación de los pueblos mediante informes y censos. A partir de entonces y hasta 1806 los pueblos estuvieron signados por constantes vaivenes político-administrativos y conflictos jurisdiccionales. El debate en torno de la «asimilación» de las poblaciones guaraníes llegó a su climax hacia 1800 cuando el Virrey Avilés decretó la liberación del régimen de comunidad para más de 300 familias guaraníes.

Dentro de los pueblos, la superposición inherente de jurisdicciones eclesiásticas y seculares se hacía crítica en las disputas por el control de la esfera «temporal» entre administradores y curas; conflictos que alcanzaron en muchos casos altos grados de violencia. La pluralización de actores -y por tanto de discursos y de prácticas- había saturado de sentidos contradictorios las prácticas sociales y discursivas vinculadas a la «frontera». Los movimientos de grupos de diferente origen en la campaña rioplatense, hacían sumamente complejo el panorama. El mestizaje se convertía en una estrategia sumamente útil para estos grupos, por las posibilidades de acceso a la tierra y al status social, de esta forma se reforzaba la modalidad del pleiteo como estrategia para dirimir los conflictos jurisdiccionales y definir al menos temporariamente límites territoriales.

Los cambios estructurales del Litoral argentino en particular y el Río de la Plata en general habían sido el caldo de cultivo para la configuración de una realidad sociocultural sumamente compleja y dinámica. En las décadas previas al fin de siglo habían germinado nuevos actores y categorías socioculturales que, por las características intrínsecamente móviles de sus actividades socio-económicas, resistían a los «etiquetamientos» que la legislación oficial trataba de establecer sobre ellos. Este paisaje cultural daba lugar a un permanente «juego interétnico» que conllevaba la construcción y superposición local de categorías estigmatizadoras, las cuales, a pesar de no encontrar lugar en la legislación, eran de uso común en la doxa de la época. Por ejemplo, en 1778 el corregidor y cabildo de Yapeyú, el pueblo más meridional, se quejaban:

«El perjuicio que arrojan estos infieles es sobre manera perjudicial a ambas majestades y por lo mismo ocurren a notoria piedad de Vuestra Excelencia para que se digne tomar las providencias que juzgue convenientes para que se castiguen según los daños que cometen pues de lo contrario aniquilaran nuestrø pueblo, [...] facilitaran a los muchos vagos y facinerosos el que al abrigo de ellos campeen por aquellos desiertos desolando cuantas haciendas de campo poseen los vecinos de la otra banda de este Río, y por consiguiente se cada día 
más la deserción de los indios por hallar abrigo entre aquellos, solo con la mira de que les acompañen en sus irrupciones» ${ }^{53}$.

Indios «infieles» y «vagos y facinerosos» eran sólo unas pocas de las categorías estigmatizadoras. Cristalizaban realidades socioculturalmente muy diversas, surgidas de movimientos poblacionales desparejos e inorgánicos. Así, los «infieles» charrúas y minuanes, podían superponerse con desertores guaraníes de los pueblos, o tupíes colaboradores de los portugueses; o españoles, criollos y mestizos dedicados al contrabando, considerados «vagos y fascinerosos» cuando de robar ganado y de saquear los pueblos se trataba. Estas eran categorías complejamente yuxtapuestas con las tradicionales divisiones étnicas que, produciendo ambigüedades y liminalidades, escapaban a los condicionamientos de la legislación. ${ }^{54}$ Directamente asociado a este punto, el Estado persiste en la idea de homogeneizar a la población mediante el incentivo de matrimonios mixtos y la adquisición de valores y elementos de prestigio españoles. Proceso que se produce en forma descontrolada.

La organización de un movimiento poblador por parte del Estado no se concreta hasta la última década del siglo XVIII. Una serie de ensayos se habían realizado previamente por medio de establecimientos ganaderos especialmente entre los pueblos meridionales. Pero estos no diferían del modelo tradicional de ocupación territorial discontinuo.

Por ese entonces, Europa, en la tinta de los viajeros y expediciones científicas, comenzaba a redefinir su «óptica Imperial», es decir, su concepción de sí misma como empresa de conquista y de la alteridad americana como horizonte cultural. La homogeneización del «otro interno», implicaba la diferenciación con un «otro externo», y en el caso de España, este era sobre todo Portugal, cuya delimitación territorial permitiría trazar el perfil de la españolidad. Las sucesivas «partidas demarcatorias» que España destina en gran escala a la definición de los límites con Portugal, más allá de su éxito dispar, intentaban construir un «otro» de características estatales equiparables. Estas «partidas» estuvieron en muchos casos a cargo de expedicionarios consagrados, que instrumentaban nociones na-

53 Archivo General de la Nación (AGN) IX.39.5.5, Buenos Aires. La Sección Colonia del AGN cuenta con abundantes legajos referentes a estos procesos. Particularmente atractivos son los legajos del período 1775-1799 de Misiones.

54 Una de estas categorías liminales eran los «guaderíos», sujetos dedicados al cuatrerismo y al abigeato, actividades con las que probablemente se identificaban, a pesar de su composición étnica diversa. Los procesos de mestizaje han sido analizados exhaustivamente por Branislava Susnik para el caso de los 13 pueblos del Paraguay y por Juan Carlos Garavaglia respecto de los pueblos guaraníes meridionales. Sobre todo este segundo autor refiere a un proceso de «campesinización», a través del cual el Estado intentaba homogeneizar a la población mestiza e indígena. GaRAVAglia 1987 [19]; Susnik [21]; Garavaglia, Juan Carlos: Mercado interno y economía colonial. Tres siglos de la yerba mate. México, Grijalbo, 1983.

R. I., $1999, \mathrm{n}^{\circ} 217$ 
turalistas para la delimitación territorial. La intención de «fijar» la frontera tomando como base la geografía física se imponía como discurso oficial y como forma de narrar la «otredad», en funcionarios como Felix de Azara o Diego de Alvear ${ }^{55}$.

Ahora bien, ¿qué papel tenía la legislación en este proceso tan dinámico? Como vimos, las «Ordenanzas», desplegaban mecanismos de interpelación por medio de los cuales el discurso oficial imprimía, simultáneamente, imágenes de sí mismo (el Estado) y de las «otredades» a él sujetas. Un discurso socioculturalmente específico que, revestido de un tono universalista, esbozaba un nuevo «sentido de realidad» erosionando y paradójicamente también refuncionalizando nociones de la estructuración social estamental previa. Por otra parte, no se trataba de un discurso impuesto desde arriba hacia abajo, sino más bien de un relato sensible a las prácticas socioculturales que intentaba modificar. Y en este sentido, tenía como característica el ser un proceso abierto y contradictorio, un proyecto hegemónico al interior del cual pugnaban diversas fuerzas.

La tensión asimilacionismo-segregacionismo se prolongaría, sin solución de continuidad, hasta el período independiente; modulando las voces, los registros y los contenidos socio-culturales a través de los cuales se canalizaba. En los primeros años del siglo XIX, los pueblos, transformados en zona de conflicto permanente, aceleraron su desintegración económica y sociocultural.

Como cierre, hemos preferido la idea del «epílogo» para connotar el carácter abierto de estos procesos históricos. Las «Ordenanzas» habían constituido un punto de partida que, a la manera de un guión incompleto o de una partitura inconclusa, preestablecían el pulso de un «drama» sujeto a las múltiples e inesperadas contingencias de la práctica. En 1810, cuando Manuel Belgrano llega a los pueblos guaraníes y establece un nuevo Reglamento para su gobierno, apela a un discurso claramente asimilacionista, pero lo hace interpelando a la población nativa desde una nueva pertenencia globalizante: la españolidad americana.

55 ANES s/a [25] refiere al auge de las expediciones científicas a fines del XVIII. Uno de los textos más importantes de Felix de AZARA en referencia a los pueblos guaraníes es Geografía fisica y esférica de las provincias del Paraguay y Misiones guaraníes, Montevideo, 1904. Para un perfil de la figura de Azara, puede consultarse el «Estudio preliminar» de Manuel LuCENA GIRALDO y Alberto BARRUECO RODRIGUEZ a una compilación de textos del funcionario titulada Escritos Fronterizos. Madrid, C.S.I.C. Clásicos, ICONA, 1994. Otros funcionarios de la época escribieron crónicas y memorias para la «imaginarización» de la realidad sociocultural de los pueblos guaraníes y sus alrededores. Por ejemplo, ALVEAR, Diego de: «Relación geográfica e histórica del territorio de las Misiones», y DoBLAS, Gonzalo de: «Memoria histórica, Geográfica, política y económica sobre la Provincia de Misiones de indios guaraníes», publicadas respectivamente en los tomos IV y III de ANGELIS Pedro de: Colección de obras y documentos relativos a la historia antigua y moderna de las Provincias del Río de la Plata. Buenos Aires. Plus Ultra. 1836-1837. Resulta interesante desde un punto de vista global, y a pesar de algunos errores fácticos no despreciables, la perspectiva de Mary Louis PRATT en su libro Ojos Imperiales.Literatura de viajes y transculturación. Buenos Aires, UNQui, 1997.

R. I., 1999, n. $^{\circ} 217$ 
In this paper, we analyze the cultural basis of some legal measures taken by the crown focusing on the construction of hegemonic images of the State, articulated to the ones of the native population.

In 1768 the Jesuits were expelled from the guarani towns of the «Jesuit Province of Paraguay». For over 150 years these Reducciones were coherent with an indigenous segregation policy promoted by the Indian legislation. The new government applied a series of measures reinforcing the state's images breaking the previous segregation paradigm and definining a political tendency for the assimilation of the native population in colonial the society.

R. I., $1999, \mathrm{n}^{\circ} 217$ 